\title{
Analysis of Students' Error in Learning of Quadratic Equations
}

\author{
Effandi Zakaria (Corresponding Author) \\ Department of Educational Methodology and Practice \\ Faculty of Education, Universiti Kebangsaan Malaysia \\ 43650 Bangi, Selangor, Malaysia \\ Tel: 60-3-8921-6279 E-mail: effandi@ukm.my \\ Ibrahim \\ Faculty of Education \\ Universiti Kebangsaan Malaysia, 43650 Bangi, Selangor, Malaysia \\ Siti Mistima Maat \\ Mathematics Unit, Technical Foundation Section \\ Universiti Kuala Lumpur Malaysia France Institute, Bangi, Selangor, Malaysia \\ E-mail: sitimistima@gmail.com
}

\begin{abstract}
The purpose of the study was to determine the students' error in learning quadratic equation. The samples were 30 form three students from a secondary school in Jambi, Indonesia. Diagnostic test was used as the instrument of this study that included three components: factorization, completing the square and quadratic formula. Diagnostic interview was also used to identify at which level students' errors occur in solving problems. The type of error is based on Newman Error Hierarchy Model that includes reading type error, comprehension, transformation, process skill, and encoding error. Data was analyzed using descriptive statistics: percentage and frequency. The findings showed that most students make error in transformation and process skill in solving quadratic equations. There was no error found in reading. The number of students who made encoding error and carelessness was small. The students' error in solving quadratic equation was due to their weaknesses in mastering topics such as algebra, fractions, negative numbers and algebraic expansions.
\end{abstract}

Keywords: Quadratic equation, Comprehension error, Transformation error, Process skill error

\section{Introduction}

Problems that arise within the education system are very complex, including the problems associated with mathematics. Mathematics is the basic knowledge needed by students to extend their learning to a higher level. Even mathematics is required in our daily lives, regardless of educational background and social life. The benefit of mathematics is not only limited to knowledge in computation, but more important, when each individual can master mathematics well, then their pattern of thinking is more rational and critical. The principles of mathematics enable people to see the problems as facts not as fiction (Hudoyo, 1998).

National Council of Teachers of Mathematics (2000) has emphasized the goal of mathematics education reform is to produce students who are skilled in resolving problems, in addition to fostering attitudes, interests and a high motivation towards mathematics. Students should be exposed to skills in interpreting problems, planning solutions strategy, implementation of plan and rechecking of answers. In order for the students to think mathematically, students should be exposed to various strategies of problem solving by doing each step carefully, and systematically.

Error in solving mathematical problems often occurs either in writing, or orally. During the process of teaching and learning mathematics, students will face many obstacles because problem solving in mathematics is a skill that is very complex. Sometimes students know how to answer the question stated, but careless in computation. According to reports of the Third International Mathematics and Science Study (TIMSS, 1999), Indonesian students ranked 34th out of 38 countries at the international level. It shows mastery of mathematics among students in Indonesia as a whole is still weak. This weakness may be due to the learning process that focus more on rote learning, involves less group work, interaction and communication. The mastery of basic mathematical knowledge is essential in concept development. Without a clear understanding of basic concepts and skills learned in the early stages, will result in the learning process becomes more difficult at the next stage. This occurs because the learning process in mathematics is categorized as hierarchical learning process (Liew \& Wan Muhammad, 1991). Mathematical concepts are interrelated with one another. 
The result of National Evaluation of Learning Study (EBTANAS, 2007) for 2001 to 2007 in Jambi Province for the subjects of mathematics is still very low. The report by the Education Ministry of the State of Jambi (Dinas Pendidikan Propinsi Jambi) has shown that the performance is still low and has not yet achieved the target. There are many errors performed by the students particularly in solving quadratic equations. Most errors are found in solving quadratic equations as compared to other topics. The reason of the occurrence of the errors is because students have difficulty in solving quadratic equations. A study by Clarkson (1991) found that comprehension errors make up a high proportion of the errors made when students attempt to solve mathematical word problems. However, Norasiah (2002) found that most students in her study made comprehension and process skill errors. Findings by Noraishiyah (2002) revealed that process skill errors are the most common.

The conceptual framework that is used in this study is based on Newman Error Hierarchical Model. The model of error investigation proposed by Newman (1997) has proved to be a reliable model for mathematics teachers. The framework has six types of errors: reading error, comprehension, transformation, process skill, encoding error and carelessness. The Newman Error Hierarchical Model is suitable to be used in identifying students' error in mathematics. This model has the hierarchy that classifies types of error based on the problem solving level done by students. According to Clements and Ellerton (1996), Newman used the word "hierarchy" because she reasoned that failure at any level of the sequence prevents students from obtaining satisfactory solutions. Prakitipong and Nakamura (2006) pointed out, in the process of problem solving there are two kinds of obstacle that hinder students from arriving at correct answers:

(a) Problems in linguistics fluency and conceptual understanding that correspond with level of simple reading and understanding meaning of problems, and

(b) Problems in mathematical processing that consists of transformation, process skills, and encoding answers.

This classification implies that the students have to interpret the meaning of the question before they proceed to mathematical processing to obtain appropriate answer.

The outcome of the written students' work in their test will be evaluated according to the type of error in Newman Error Hierarchical Model based on the first breakdown point. The conceptual framework is shown in Figure 1

\section{Purpose and Objective of the study}

The purpose of this study was to analyze students' error in learning quadratic equations which focused on subtopics such as factorization, completing the square and quadratic formula. The following are the objectives of the study:

a) to determine the type of students' error in using factorization

b) to determine the type of students' error in using completing the square method.

c) to determine the type of students' error in using quadratic formula.

\section{Methodology}

This study is a case study that used a survey method. The respondents were 30 Form Three students from a secondary school in Jambi, Indonesia. The justification of selecting these students as respondents are as follows i) easy access to school, ii) has a situation that is rich in process and sample iii) the researchers can develop a close relationship with the sample, thus the quality and credibility of research data will be more secured.

\subsection{Instrumentation}

The study used a set of test question to identify type of students' error. The researcher developed all the items and made some modifications. The final instrument with 16 items has three subtopics: factorization, completing the square and quadratic formula. The Cronbach alpha reliability coefficient of the instrument is 0.83 . The discrimination index is more than 0.3. Therefore, all items of the instruments are acceptable as good item (Abd Rashid \& Siti Rahayah, 2001).

The subtopic of factorization has 6 questions, 5 questions for completing the square and 5 questions for quadratic formula. The researcher also interviewed the respondent. The interview procedure was based on a modified Newman Error Hierarchical Model and it was conducted if the respondent failed to answer correctly in their written test. If they managed to get the answer correct for the second time then the first error that they make would be considered as carelessness. If the answer was wrong again for the second time then the students were required to read the question and explained what is required by the question. They were also asked to interpret 
the quadratic problem, perform operation and write the answer. Table 1 below shows the number of items according to subtopics and the tested skills.

The researcher referred the instrument to two experts who were mathematics teachers who have more than 17 years experience in teaching mathematics in order to check the validity of the instrument. Any inappropriate items were modified as suggested by the experts in order to suit with the purpose of the study.

Respondent were interviewed based on Newman interview procedure. The following are the questions of the interview:

i) Can you read the problem? (Reading level)

ii) What does the question ask you to do? (Comprehension level)

iii) What do you use to solve the question? (Transformation level)

iv) Can you show me the working steps that you have used in order to find the answer? (Process Skills)

v) Tell me what is your answer? (Encoding)

\section{Results}

The respondent's profile according to gender and their achievement is represented in Table 2 below. As shown in Table 2, the students are grouped in three different category of achievement: low, medium and high. The school has classified students' achievement based on placement test. Three (3) male and four (4) female students belong to high category, the medium category has 5 males and 7 females and the low category has 6 males and 5 females.

\subsection{Type of Error in Using Factorization}

For item 1 to 6 , most type of error made by students in using factorization to determine the root of a quadratic equation were transformation errors followed by process skill errors. The details of the error type based on item are shown in Table 3.

\subsection{Type of Error in Using Completing the Square Method}

For item 7 to 11, there are a total of 16 comprehension error, 46 transformation error, 55 process skill error, 4 encoding error and 1 carelessness. Most type of errors made by students were process skill errors. The details of the error made according to their type are shown in Table 4.

\subsection{Type of Error in Solving Quadratics Equation Using Quadratic Formula}

For item 12 to 16, there are a total of 8 comprehension error, 55 transformation error, 71 process skill error, 2 encoding error and 3 carelessness. In solving quadratics equation using quadratic formula, it was found that most students made process skill errors. The details of the error made according to their type are shown in Table 5. The findings of this study conclude that the error made in learning quadratic equations consist of error in comprehension, transformation, process skill, encoding and carelessness. However, most of the errors made were transformation and the process skill errors.

\section{Discussion}

\subsection{Type of error in using factorization}

The most frequent errors made by student in using factorization include comprehension error, transformation error and process skill error. They have problem in the meaning of the word root. Most comprehension errors occur when students do not understand the terms used. Students' often misunderstood what the question wants. This weakness is probably due to the lack of emphasize by teachers in teaching the factorization method. Teachers must ensure that the teaching of mathematical concepts must be balanced with the arithmetic skills. The findings of the study are supported by the research of Intanku (2003), Norasiah (2002), Rahim (1997) and Roslina (1997). They agreed that students always make error in understanding the terms used since the mathematical terminology is being ignored.

The error type in transformation occurred during computation process especially during multiplication. This takes place due to computation problem especially among low achievers. Based on Norasiah (2002), most students make error at the process skill level especially in the expansion of quadratics expression. In computation, the students make mistake in positive and negative sign when developing algebraic expressions. Errors also occur when replacing value that has a negative sign. The findings of the study support the research of Norasiah (2002), Roslina (1997) and Parish \& Ludwig (1994) that most low and average students face difficulty in factorization and simplifying algebraic expressions as well as performing algebraic operations. 


\subsection{Type of error in completing the square}

In completing the square, students have shown the tendency to make error in transformation and process skill. This error occurs because students failed to understand and describe what is required by the questions. Most students did not manage to perform the completing the square method. This results in failure to solve the problems. Results of this study concurred with the findings of Norasiah (2002) and Rahim (1997), in which problematic students failed to translate mathematical problems into mathematical form and also having problem understanding the special terms in mathematics. This failure may be caused by lack of emphasis by teachers on understanding the language of mathematics and the skills needed by the students. This may also result from the failure or inability of teachers to ensure that every student master the basic skills before moving to new topics. Graham et al. (1999) concluded that the learning of mathematics at the early stage should focus on the development of concept inorder to prepare for learning of advance concept at the higher level. This type of transformation error occurs when the students failed to see carefully and clearly what is required by the questions. As a result, they write the answers that are not suitable with concepts and method that they have learnt.

\subsection{Type of error in Solving Quadratics Equation Using Quadratic Formula}

Transformation errors and process skill errors are the most errors found among students in solving quadratics equation using quadratic formula. The students have problem in computation and applying the quadratic formula. Examples of process skills errors committed by students involve the operation of addition, subtraction, multiplication and division. At the same time students also experienced difficulties in replacing the positive and negative sign, resulting in errors in using the formula. Although there are some other errors in solving quadratic equations such as carelessness and encoding errors, the number of errors are small. Results of this study are in line with the research findings of Liew and Wan Muhammad (1991). The emphasis on algorithmics skills without explanation on the concept or principle are the factors that cause difficulties in mathematics.

\section{Conclusion}

The results of this study revealed that most error are transformation errors and process skills errors. Research on analysis of students' error in solving quadratic equations will be of most benefit to teachers in secondary mathematics. The analysis of each student's problem will enable the teachers to plan their teaching effectively and meaningful. Based on the analysis, teachers will identify the roots of the problems in students' learning. As a result, the outcome of the research can be shared with their colleagues in order to solve the students' problem. This study will also help mathematics educators get information on the students' problem in mathematics learning. Inorder to counter students' problem, teachers should be well prepared and be able to conduct analysis on students learning. The findings of this study can be as a reference for teachers to find alternative ways in solving students' problem especially in solving quadratic equations.

\section{References}

Abd. Rashid Johar \& Siti Rahayah Ariffin. (2001). Isu pengukuran dan penilaian pendidikan.[Measurement and Evaluation Issues in Education]. Bangi: Universiti Kebangsaan Malaysia Publisher.

Clarkson, P.C. (1991). Language comprehension errors: A further investigation. Mathematics Education Research Journal, 3(2),25-33.

Clements, M.A. \& Ellerton, N.F. (1996). The Newman procedure for analysing errors on written mathematical tasks. Retrieved January 12, 2010, from http://compasstech.com.au/ARNOLD/ PAGES/newman.htm

EBTANAS (2007). Laporan Hasil Evaluasi Pembelajaran [Learning Evaluation Report], Provinsi Jambi.

Graham, A., Cynthia, W., Langgrall, C. A., Thornton \& Timothy, M.A. (1999). Students' probabilistic thinking in instruction. Journal for Research in Mathematics Education 30(5):487-519.

Hudoyo, H. (1998). Pembelajaran Matematika Menurut Pandangan Konstruktivistik. [Learning mathematics through contructivist perspectives]. Conference Paper Seminar Nasional Upaya Meningkatkan Peran Pendidikan Matematika dalam Menghadapi Era Globalisasi. PPS IKIP Malang.Indonesia

Intanku Salwa Shamsuddin. (2003). Diagnosis Jenis Kesilapan Pelajar dalam Pembelajaran Perbezaan. [Diagnosis for the type of error in differentiation] Master of Education Research Project. Universiti Kebangsaan Malaysia.

Liew, S.T. \& Wan Muhamad Saridan Wan Hasan. (1991). Ke arah memahami dan mengurangkan kesukaran dalam pembelajaran matematik. [Understanding and minimizing difficulty in learning mathematics] Berita Matematik, 38, 22-29 
National Council of Teachers of Mathematics. (2000). Curiculum and Evaluation Standards for School Mathematics. Reston. V A : National Council of Teachers of Mathematics.

Newman, M.A. (1977). An analysis of $6^{\text {th }}$ grade pupils' errors on written mathematical task. Dlm. Clements, M.A. \& Foyster, J. (Eds). Research in Mathematical Education in Australia: 239-258.

Noraisyiah Abdullah. (2002). Pembentukan ujian untuk mengenalpasti kelemahan asas matematik pelajar di sebuah Institusi Pengajian Tinggi Teknikal. [Development of a test to determine the weakness in basic mathematics among Higher Technical Institute students]. Master of Education Research Project. Universiti Kebangsaan Malaysia.

Norasiah Ambia (2002). Diagnosis jenis kesilapan dalam hierarki Pembelajaran Serentak. [ Error type diagnosis in learning simultaneous equation]. Master of Education Research Project, Universiti Kebangsaan Malaysia.

Parish, C.R. \& Ludwig, H.J. (1994). Language, intellectual structures and common mathematical errors: a call for research. School Science and Mathematics. 94(5), 235-239.

Prakitipong, N. \& Nakamura, S. (2006). Analysis of mathematics performance of Grade 5 students in Thailand using Newman procedure. Journal of International Cooperation in Education, 9(1), 111-122.

Rahim Mohd Nor (1997). Kemahiran penyelesaian masalah matematik dikalangan pelajar menengah rendah. [Problem solving skills among Lower Secondary School students]. Master of Education Research Project. Universiti Kebangsaan Malaysia.

Roslina Radzali. (1997). Keupayaan algebra asas pelajar tingkatan empat sekolah menengah kerajaan Daerah Hulu Langat.[The ability of Form Four students in basic algebra]. Master of Education Research Project. Universiti Kebangsaan Malaysia.

Skemp, R.R. (1979). Goals of learning and Qualities of understanding. Mathematics Teaching. 88, 44-49.

TIMSS.(1999). International Students Achievement in Mathematics. http://timss:bc.edu/timss1999i/pdf/T99i math 01.pdf.

Table 1. Number of Items According to Skills

\begin{tabular}{llll}
\hline Subtopic & Skill & Item Number & Number of Item \\
\hline Factorization & $\begin{array}{l}\text { Determine the root of } \\
\text { quadratic equation using } \\
\text { factorization }\end{array}$ & $1-6$ & 6 \\
\hline Completing the square & $\begin{array}{l}\text { Solving quadratic } \\
\text { equation using } \\
\text { completing the square } \\
\text { method }\end{array}$ & $7-11$ & 5 \\
\hline Quadratic formula & $\begin{array}{l}\text { Solving quadratic } \\
\text { equation using a formula }\end{array}$ & 5 \\
\hline
\end{tabular}

Table 2. Respondent's Profile

\begin{tabular}{clcc}
\hline Profile & Category & Frequency & Percentage (\%) \\
\hline Gender & Male & 14 & 46.7 \\
\cline { 2 - 4 } & Female & 16 & 53.3 \\
\hline $\begin{array}{c}\text { Achievement } \\
\text { Male }\end{array}$ & Low & 6 & 20.00 \\
\cline { 2 - 4 } & Medium & 5 & 16.67 \\
\cline { 2 - 4 } & High & 3 & 10.00 \\
\cline { 2 - 4 } Female & Low & 5 & 16.67 \\
\cline { 2 - 4 } & Medium & 7 & 23.33 \\
\cline { 2 - 4 } & High & 4 & 13.33 \\
\hline
\end{tabular}


Table 3. Type of Error in Factorization

\section{Frequency of Error}

Item Reading Comprehension Transformation Process Skill Encoding Carelessness

\begin{tabular}{cccccc}
\hline 1 & 3 & 5 & 8 & 4 & 2 \\
2 & 5 & 13 & 9 & 3 & \\
3 & 3 & 17 & 10 & & \\
4 & 5 & 13 & 11 & & \\
5 & 2 & 12 & 9 & 6 & \\
6 & 16 & 16 & 14 & 13 & 2 \\
\hline Total & 18 & 76 & 61 &
\end{tabular}

Table 4. Type of Error in Completing the Square

\section{Frequency of Error}

\begin{tabular}{cccccc}
\hline \multicolumn{7}{l}{ Reading Comprehension Transformation Process Skill } & Encoding & Carelessness \\
Item & 2 & 4 & 7 & 1 & 1 \\
\hline 7 & 3 & 7 & 6 & 3 & \\
8 & 2 & 9 & 11 & & \\
9 & 4 & 11 & 14 & & \\
10 & 5 & 15 & 17 & & 1 \\
11 & 16 & 46 & 55 & 4 & \\
\hline Total & & &
\end{tabular}

Table 5. Type of error in solving quadratics equation using quadratic formula

Frequency of Error

\begin{tabular}{cccccc}
\hline Item & Reading & Comprehension Transformation Process Skill & Encoding & Carelessness \\
\hline 12 & 3 & 7 & 12 & 2 & 1 \\
13 & 2 & 9 & 11 & & \\
14 & 1 & 10 & 20 & \\
15 & 2 & 12 & 15 & \\
16 & & 17 & 13 & & \\
\hline Total & 8 & 55 & 71 & 2 & 3 \\
\hline
\end{tabular}

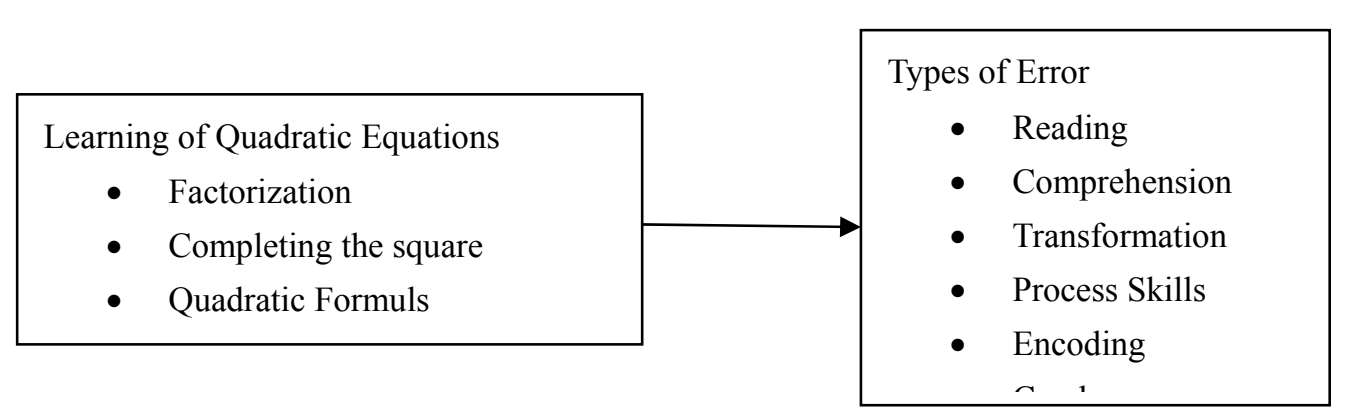

Figure 1. Conceptual Framework of the study. 